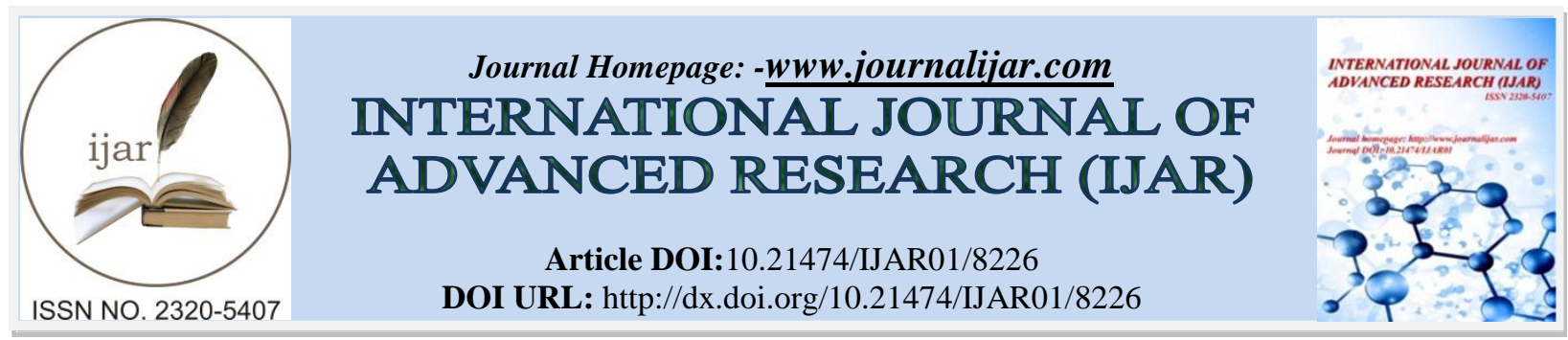

RESEARCH ARTICLE

\title{
PREVALENCE, PHENOTYPIC AND GENOTYPIC CHARACTERIZATION OF GALLIBACTERIUM ANATIS ISOLATED FROM LAYER.
}

Ashraf A. Abd El Tawab ${ }^{1}$, Waffaa M. Hassan ${ }^{2}$ and Mariam M. El Shemy ${ }^{3}$.

1. Bacteriology, Mycology and Immunology Department Faculty of Veterinary Medicine Benha University.

2. Reference laboratory for quality control on poultry production.

3. Animal Health Research Institute ,Tanta branch.

\section{Manuscript Info}

\section{Manuscript History}

Received: 18 October 2018

Final Accepted: 20 November 2018

Published: December 2018

Key words:-

Gallibacterium anatis, peritonitis, rtx, virulence genes, resistant genes.

\begin{abstract}
Gallibacterium anatis is one of the most important microorganisms causing peritonitis in layer chickens. The present study was planned for bacteriological examination of $\mathrm{G}$. anatis and characterization the molecular bases of virulence and antimicrobial resistance of isolated strains. In the current study a total of 50 egg laying chickens were collected from different chicken farms at AL Gharbia governorate, at the period of (2016-2017) samples from (trachea, ovary and oviduct swab) were taken and cultivated on Columbia blood agar, Sheep blood agar, MacConky's agar and Dextrose starch agar media for isolation of G.anatis. The results revealed that $8(16 \%)$ of samples were positive for G. anatis isolation. Furthermore, the isolates were subjected to PCR for confirmation, where only $4(8 \%)$ of isolates were positive for $16 \mathrm{~S}$ rRNA23S rRNA. All isolates were sensitive to gentamicin,cefotaxime and ciprofloxacin while, they were resistant to oxytetracyclin and doxycycline which could be explained by the presence of (100\%) tetH gene in all tested isolates. Amplification of ( gtxA ( $\mathrm{rtxA}$ ),gyrB and fifA) genes revealed (100\%) detection of gtxA and gyrB genes, while none detection of fifA gene in all tested strains. Consequently, PCR is more specific and it is considered rapid and confirmative type of identification and further studies needed to prepare vaccine against it to overcome the disease and drug resistance.
\end{abstract}

Copy Right, IJAR, 2017,. All rights reserved.

\section{Introduction:-}

Gallibacterium is a new genus of the family Pasteurellaceae which previously reported as Actinobacillus salpingitidis, Pasteurella anatis, and avian Pasteurella haemolytica-like organisms (Christensen et al., 2003a).The genus Gallibacterium contains 5 named species; G. anatis Biovar haemolytica, G.melopsittaci, G. anatis biovar anatis, G. trehalosi-fermentans, G. genomospecies, 1,2, 3, un-named taxon and G. salpingitidis, (Christensen et al., 2003b, Bojesen., 2003 and Janda, 2011).G. anatis is included two biovars: the non hemolytic biovar anatis and the bhemolytic biovar hemolytic (Christensen et al., 2003a).

G. anatis is normal inhabitant in the lower genital tract and upper respiratory tract of different healthy birds and responsible for a wide range of pathological lesions, especially in the egg-laying chicken causing salpingitis and

Corresponding Author:-Ashraf A. Abd El Tawab.

Address:-Bacteriology, Mycology and Immunology Department. 
peritonitis, leading to decreased egg-production and high mortality (Bojesen et al., 2004, Jordan et al.,2005 and Neubauer et al.,2009).

Gallibacterium species are Gram-negative rod-shaped or pleomorphic disterputed singly or in pairs and non-motile. Colonies are grayish and non-transparent with strong hemolytic zone on Sheep blood agar, but eventually translucent at the periphery with a butyrous consistency, circular, raised with an entire margin smooth, shiny, and 1$2 \mathrm{~mm}$ in diameter at $37^{\circ} \mathrm{C}$ for 24-48 hrs. nonspore forming. Grow under microaerophilic condition. positive for Catalase, oxidase, and phosphatase but negative for indole and urea (Christensen et al.,2003a). Prevalence proportions of haemolytic G. anatis was highly influenced by the production system and the biosecurity levels (Bojesen et al., 2003).

G. anatis F149T has ability to express fimbriae which responsible for mucosal attachment and colonization to oropharyngeal epithelial cells (Salgado-Lucio et al.,2012).

$\mathrm{G}$.anatis is able to produce a cytolytic RTX-toxin as a virulence factor which responsible for hemolytic phenotype and leukocytic activity. (Kristensen et al.,2010).

Identification of Pasteurellaceae members by traditional methods are difficult in culturing, isolation and weak reactions toward some of the phenotypic tests used for identification (Christensen et al.,2003) Consequently, the aim of the present study was to apply a PCR specific for G.anatis to allow accurate and unambiguous identification, where G.anatis had a relatively short internal transcribed 16S to 23S rRNA gene sequence compared to other members of Pasteurellaceae and to focus on its virulence and resistance genes.

\section{Materials And Methods:-} collection of samples:-

50 egg laying chickens (recently dead and diseased) suffering from peritonitis, salpingitis and decreased egg production were collected from Al-Gharbia Governorate in the period of (2016-2017) samples from (trechea, ovary and oviduct swabs) were aseptically collected and transferred immediately in ice box to the laboratory.

\section{Bacteriological examination of the samples:-}

The samples were identified on the basis of Gram staining after streaking into media as: Columbia blood agar, Sheep blood agar, MacConky's agar and Dextrose starch agar media (oxoid).

After cultured on media incubated at $37{ }^{\circ} \mathrm{C}$ for 24 hours with $7.5 \% \mathrm{CO} 2$.

Each colony has shown a typical colonial appearance was subjected to staining by Gram's and giemsa stain. Biochemical identification was examined for catalase, oxidase, indole and urea tests. according to Christensen et al.,2003a.

\section{Congo red binding test:-}

Congo red binding test was conducted for detection of virulence G. anatis according to Berkhoff and Vinal,1986.

\section{Extraction of DNA and PCR Conditions:-}

The isolates were cultivated on 5\% citrated bovine blood agar overnight. A single colony was incubated at $37^{\circ} \mathrm{C}$ on brain heart infusion broth. Both DNA extraction and Emer-ald Amp GT PCR master mix preparations were conducted using commercial kits (Takara Bio Inc., Shiga, Japan) according to the manufacturer's instructions. (Sambrook et al., 1989).

\section{Antimicrobial suscessptabilty test for Gallibacterium anatis:-}

G. anatis isolates were cultured on blood agar plate containing $10 \%$ sheep blood. The colonies were scrapped out and re-suspended in Brain heart infusion broth to a turbidity of $0.5 \mathrm{McFarland}$ scales. One hundred microlitres of the culture was swabbed onto the brain heart infusion agar according to Bauer et al., 1966 then the following antibiotic discs erythromycin $(15 \mu \mathrm{g})$, gentamicin $(10 \mu \mathrm{g})$, doxycycline $(30 \mu \mathrm{g})$, oxytetracyclin $(15 \mu \mathrm{g})$, ciprofloxacin $(5 \mu \mathrm{g})$, cefotaxime $(30 \mu \mathrm{g})$, sulfadimethoxine trimethoprim $(25 \mu \mathrm{g})$ and amoxicillin|clavulinic acid $(30 \mu \mathrm{g})$ were dispensed on media and incubated over night at $37^{\circ} \mathrm{C}$ under microaerophilic condition. inhibition zones were interpreted according to the criteria recommended by the Clinical and Llaboratory Standerds Iinstute (CLSI,2011). 


\section{Detection of resistance and virulence genes:-}

The different primers used in this study are described in Table (1).

Table 1:-Oligonucleotide primers and sequences encoding for detection of Common gene, gyrB, flfA, gtxA and tetH genes.

\begin{tabular}{|c|c|c|c|}
\hline Target gene & Primers sequences $5^{\backslash}-3$ & $\begin{array}{c}\text { Amplified } \\
\text { segment (bp) }\end{array}$ & Reference \\
\hline \multirow{2}{*}{$\begin{array}{l}16 \mathrm{~S} \text { rRNA- } \\
23 \mathrm{~S} \text { rRNA }\end{array}$} & FTATTCTTTGTTACCARCGG & \multirow[t]{2}{*}{1032} & \multirow[t]{2}{*}{ Bojesen et al.,(2007) } \\
\hline & RGGTTTCCCCATTCGG & & \\
\hline \multirow[t]{2}{*}{ gyrB } & FTGTGCGTTTCTGGCCAAGTC & \multirow[t]{2}{*}{561} & \multirow{2}{*}{$\begin{array}{c}\text { Johnson et al., } \\
(2013)\end{array}$} \\
\hline & RCGCTCACCAACTGCAGATTC & & \\
\hline \multirow[t]{2}{*}{$\operatorname{gtxA}(\mathrm{rtx})$} & F CAAACCTAATTCAATCGGATG & \multirow[t]{2}{*}{1257} & \multirow[t]{2}{*}{ Paudel et al., (2013) } \\
\hline & R TGCTTCAATAATTTTCCATTTTC & & \\
\hline \multirow[t]{2}{*}{ fifA } & F CACCATGGGTGCATTTGCGGATGATCC & \multirow[t]{2}{*}{538} & \multirow[t]{2}{*}{ Bager et al., (2013) } \\
\hline & R TATTCGTATGCGATAGTATAGTTC & & \\
\hline \multirow[t]{2}{*}{ tetH } & F ATACTGCTGATCACCGT & \multirow[t]{2}{*}{1076} & \multirow[t]{2}{*}{ Klima et al., (2014) } \\
\hline & R TCCCAATAAGCGACGCT & & \\
\hline
\end{tabular}

\section{Results:-}

Incidence of G.anaitis in layer chickens:-

In the present study out of 50 egg laying chickens suffering from peritonitis, salpingitis and decreased egg production 8/50(16\%) were positive for G.anaitis isolation. Clinically examined birds showed signs of restlessness, ruffled feathers and drop in egg production. P.M lesions were, septicemia, peritonitis, salpingitis and degeneration in egg follicle. The recovered isolates were iridescent on Dextrose Starch Agar medium and show concentric rings. Sub-culturing on MacConkey's agar showed no growth. Colonies of G.anatis on Blood agarcharacterized by circular, raised colonies with entire margin, shiny and semi-transparent with a $\beta$ hemolytic. Morphological examination of G.anatis organisms appeared as Gram-negative, rod-shaped or pleomorphic, cells disterputed singly or in pairs, non-spore forming, non-motile, bipolar staining when stained by giemsa stain. The results of biochemical identification showed characteristic identical biochemical reaction to be G.anatis positive catalase, oxidase, and negative urease and indol test. The phenotypical studies ensured that all isolates were virulent when detected by congo red test. furthermore, the isolates were subjected to PCR for confirmation, where only 4/50 (8\%) of isolates were positive for $16 \mathrm{~S}$ rRNA23S rRNA. As shown in table(2).

\section{Antimicrobial sensitivity test:-}

Antibiotic sensitivity test revealed that all isolates were sensitive to gentamicine, ciprofloxacin, cefotaxime and sulfadimethoxine trimethoprim and moderate sensitive to enrofloxacin and amoxicillin claviulinic acid. while, they were resistant to oxytetracyclin and doxycycline.

\section{Molecular characterization of tetH resistant gene of G.anatis:-}

The phenotypic resistance of G.anatis to oxytetracyclin and doxycycline could be explained by the presence of $(100 \%)$ tetH gene in all tested isolates.

Molecular characterization of virulence genes of G.anatis:-

four isolates of G.anatis isolates were examined for detection of ( gtxA (rtxA),gyrB and fifA) genes, the result revealed $(100 \%)$ detection of gtxA and gyrB genes, while none detection of fifA gene in all tested strains. As shown in table 3 .

Table 2:-prevalence of G.anatis isolated from layers.

\begin{tabular}{|c|c|c|}
\hline Number of examined samples & $\begin{array}{l}\text { Number of positive after } \\
\text { boichemical tests }\end{array}$ & Number of positive after PCR \\
\hline 50 & 8 & 4 \\
\hline Percentage & $16 \%$ & $8 \%$ \\
\hline
\end{tabular}


Table 3:-result of PCR virulence and resistant genes of G.anatis .

\begin{tabular}{|c|c|c|c|c|}
\hline Sample & tetH & fifA & gyrB & Gtx \\
\hline 1 & + & - & + & + \\
\hline 2 & + & - & + & + \\
\hline 3 & + & - & + & + \\
\hline 4 & + & - & + & + \\
\hline
\end{tabular}

\section{Discussion:-}

Peritonitis is an important disease of laying chickens, G. anatis is one of the most important microorganisms causing peritonitis. The results of isolation revealed that $8(16 \%)$ of samples were positive for $\mathrm{G}$. anatis after bacteriological isolation. This result nearly agreed to El Bestawy 2014 who obtained $7 \mathrm{G}$. anatis isolates from only 5 positive commercial layer flocks (5/38) (13.1\%).but this result disagreed to that recorded by Abd El-Hamid et al.,2016 where they isolated G. anatis by $23.43 \%$. This low incidence could be due to the good management, high biosecurity, absent of stress factors as mixed infection with other microorganisms, seasonal changes, immunological status may be the real cause of low incidence (Bojesen et al., 2004). Furthermore, the isolates were subjected to PCR for confirmation, where only $4(8 \%)$ of isolates were positive for $16 \mathrm{~S}$ rRNA23S rRNA where amplicon at $1032 \mathrm{bp}$. This result agreed with Bojesen et al., 2007 who recorded that the forward and reverse primers set (1133fgal-114r) amplicated specifically the DNA of G. anatis at amplicon of $790 \mathrm{bp}, 1032 \mathrm{bp}$ and $1080 \mathrm{bp}$. The difference between bacteriological and PCR percent could be due to difficulties at isolation, culturing of Pasteurellaceae members by traditional means and weak reactions toward some bacteriological tests Christensen et al., 2003)

Extensive and miss use of antimicrobial drugs in poultry industry is the main cause of resistance to commonly used antibiotics and rising of multi-drug resistant strains (Sharada et al .,2009). In the present study G.anatis isolates were highly sensitive to gentamicine, cefotaxime, ciprofloxacin and sulpha. trimethoprim, while moderate sensitive to enrofloxacin and amoxicillin with calivulinic acid. On the other hand all isolates were complete resistant to oxytetracyclin and doxycycline. This result agreed with Bojesen et al. (2011), who noted that 97\%of field strains were resistant to tetracycline, also agreed with Dewhirst et al., (1993); Janda (2011) and Jones et al., (2013).Other result optained by Bojesen et al.(2007) who recorded that all isolates were sensitive to amoxicillin-calivulinic acid and El Bestawy 2014 who recorded that they resistant to sulpha. Trimethoprim. The differences in resistance patterns are widely due to factors which include differences in geographical locations, particular bacteria species involved, the animal production systems, the extent to which antibiotics are used, sampling techniques and period of sampling (Adzitey et al.,2015).

The molecular investigations of resistance mechanisms of G.anatis isolates to oxytetracyclin and doxycycline which could be explained by the presence of $(100 \%)$ tetH gene in all tested isolates.

G.anatis infections are usually associated with the presence of virulence genes, $\mathrm{G}$.anatis is able to produce a cytolytic RTX-toxin as a virulence factor which responsible for hemolytic activity against erythrocytes of hosts and leukotoxic activity (Kristensen et al.,2010).In the current study the gtxA gene was detected in all isolates but flfA gene was not detected in all isolates. This result was disagree to that recorded by Sorour et al., (2015) where they detected fifA gene in $50 \%$ of isolates. This could be due to the F17-like fimbria is encoded by a four-gene designated as flfD, flfC, flfG and flfA ( Bager et al., 2013) or due to sub-cultivation of strains which lead to loss of virulence factors expression.

\section{Conclusion:-}

1. G. anatis is one of the most important microorganisms causing salpingitis, peritonitis and drop in egg production.

2. PCR is more accurate than traditional method in detection of G.anatis.

3. RTX-like toxin is the main virulence factor of $\mathrm{G}$. anatis named gtxA which responsible for evoking the phenotypic character of strain such as hemolysis

4. The drug of choice against G.anatis are gentamicin ,ciprofloxacin, cefotaxime and sulfadimethoxine trimethoprim.

5. Further studies and genes sequences required to G.anatis to prepare vaccine against it to overcome the disease and drug resistance. 


\section{References:-}

1. Abd El Hamid H S, Ellakany H F, Bekheet A A, El bestawy A R and Nahla M, 2016.pathogenicity of ten

2. Gallibacterium Anatis isolates in commercial broiler chickens.Alex.J.Vetscien.49:(2):42-49.

3. Adzitey F, Teye G.A, and Anachinaba I A, (2015): Microbial quality of fresh and smoked guinea fowl meat sold in the Bolgatanga Municipality, Ghana. Asian Journal of Poultry Science, 9: 165-171.

4. Bager R J, Nesta B, Pors S E, Soriani M, Serino L,Boyce J D, Adler B and Bojesen A M, 2013. The fimbrial protein flfA from Gallibacterium anatis is a virulence factor and vaccine candidate. Infect. Immun. 81:19641973.

5. Bauer A W, Kirby W M, Sherris J C and Turck M, 1966.Antibiotic susceptibility testing by a standardized

6. single disk method. Am. J. Clin. Pathol. 45:493-496.

7. Berkhoff $\mathrm{H}$ and Vinal A C, 1986. Congo red medium distinguish between invasive and non invasive Escherichia coli pathogenic for poultry. Avian disease, 30:117-121.

8. Bisgaard M, Korczak B M, Busse H J, Kuhnert P, Bojesen A M and Christensen H, 2009. Classification of the taxon 2 and taxon 3 complex of Bisgaard within Gallibacterium and description of Gallibacterium melopsittaci sp. nov., Gallibacterium trehalosifermentans sp. nov. and Gallibacterium salpingitidis sp. Int .J .Syst. Evol. Micr, 59: 735-744.

9. Bojesen A M, 2003.Gallibacterium infection in chickens. PhD, Thesis, Dep. Vet. Microb., Royal Vet. And Agricul. Univ. Frederiksberg, Denmark.

10. Bojesen A M, Nielsen S S And Bisgaard M, 2003. Prevalence and transmission of haemolytic Gallibacterium species in chicken production systems with different biosecurity levels.Avian Pathology, 32:503-510.

11. Bojesen A M, Nielsen O L, Christensen J P and Bisgaard M, 2004. In vivo studies of Gallibacterium Anatis infection in chickens. Avian Pathol, 33: 145-152.

12. Bojesen A M, Vazquez M E, Robles F, Gonzalez C, Soriano E V, Olsen, J E and Christensen H,2007. Specific identification of Gallibacterium by a PCR using primers targeting the 16S rRNA and 23S rRNA genes. Vet. Microbiol. 123:262-268.

13. Bojesen A M, Vazquez, R J, Bager D, Ifrah C, Gonzale,z and Aarestrup. F. M. ,2011. Antimicrobial susceptibilityandtetracycline resistance determinant genotyping of Gallibacteriumanatis. Vet. Microbiol. 148:105-110.

14. Christensen H, Bisgaard M, Bojesen A M, Mutters R and Olsen J E,2003a.Genetic relationships among avian isolates classified as Pasteurella haemolytica, 'Actinobacillussalpingitidis' or Pasteurella anatis with proposal of Gallibacterium anatis gen. nov., comb. nov.and description of additional genomospecies within Gallibacterium gen. Int.J. Syst. Evol. Micr. 53: 275-287.

15. Christensen H G, Foster J P, Christensen T, Pennycott J E, Olsen E and Bisgaard M,2003b.Phylogenetic analysis16S rRNA sequence comparison of avian taxa of Bisgaard and characterization and description of two new taxa of Pasteurellaceae. J. Appl. Microbiol. 95:354-363.

16. Clinical and Llaboratory Standerds Iinstute (CLSI),2011. M07 Methods for dilution antimicrobial susceptibility testsfor bacteria . That grow aerobically,.Approved standard, 8thedn. CLSI, Wayne.

17. Dewhirst F. E, Paster B. J, Olsen, I and Fraser G J,1993. Phylogeny of the Pasteurellaceaeas determined

18. comparison of $16 \mathrm{~S}$ ribosomal ribonucleic-acid sequences. Zbl. Bakt., 279:35-44.

19. El-Bestawy A R,2014. Studies on Gallibacterium anatis infection in chickens. Ph. D Thesis in Poult. Dis., Fac. Vet. Med. Alex. Univ.

20. Janda W M, 2011.Update on Family Pasteurellaceae and the Status of Genus Pasteurella and Genus Actinobacillus. Microbiol. Newsletter, 33(18): 135-144.

21. Johnson T J, Danzeisen J L, Trampel D, Nolan LK, Seemann T, Bager R J and Bojesen A M,2013.Genome Analysis and Phylogenetic Relatedness of Gallibacterium anatis Strains from Poultry. plos one $8: 54844$.

22. Jordan F T W, Williams N J, Wattret A and Jones T,2005. Observations on salpingitis, peritonitis and salpingoperitonitis in a layer breeder flock. The Vet. Rec., 157: 573-577.

23. Jones K H, Thornton J K, Zhang Yand Mauel M.J. 2013. A 5-year retrospective report of Gallibacteriumanatis and PasteurellaMultocida isolates from chickens in Mississippi.Poult. Sci.,92(12):3166-3171.

24. Klima C L, Alexander T W, Hendrick S and McAllister T A, 2014.Characterization of Mannheimia haemolytica isolated from feedlot cattle that were healthy or treated for bovine respiratory disease. The Canadian Journal of Veterinary Research. 78: 38-45.

25. Kristensen B M, Frees D and Bojesen A M,2010. gtxA from Gallibacterium anatis, a cytolytic RTX-toxin with a novel domain organisation. Vet. Res. 41: 25-26.

26. Kristensen B M, Frees D and Bojesen AM, 2011.Expression and secretion of the RTX -toxin GtxA among members of the genus Gallibacterium. Vet.Microbiol.153:116-123. 
27. Neubauer C, De Souza-Pilz M, Bojesen A M, Bisgaard M and Hess M,2009. Tissue distribution of haemolytic Gallibacterium anatis isolates in laying birds with reproductive disorders. Avian Pathol., 38(1): 1-7.

28. Paudel S, Alispahic M, Liebhart D, Hess M and Hess C, 2013. Assessing pathogenicity of Gallibacterium anatis in a natural infection model: the respiratory and reproductive tracts of chickens are targets for bacterial colonization. Avian Pathology, 42, (6):527-535.

29. Salgado-Lucio M L, Vaca S, Vázquez C, Zenteno E, Rea I, Pérez-Márquez V M and Negrete-Abascal E,2012. Adhesion of Gallibacterium anatis to Chicken Oropharyngeal Epithelial Cells and the Identification of Putative Fimbriae. Adv. Microbiol., 2: 505-510.

30. Sambrook J, Fritscgh E F and Mentiates M,198.Molecular coloning. A laboratory manual. Vol !., Cold spring Harbor Laboratotry press, New York.

31. Sharada R, Ruban S W and Thiyageeswaran M, (2009): Antibiotic resistance pattern of E. coli isolated fromPoultry.in Bangalore. Internet J. Microbiol., 7.

32. Sorour H K, AL Atfeehy N M and Shalaby A G, 2015. Gallibacterium anatis infection in chickens and ducks. Assiut.Vet. Med. J. 61. 147. 